\title{
A ZEOLITE-SMECTITE LAYER OF TUFFS IN LOWER-VENDIAN TRAP-ROCKS OF SOUTH-WEST PARTS EAST-EUROPEAN PLATFORM, THEIR ORIGINS AND PROSPECT OF THE USE
}

\author{
V.G. Mel'nichuk
}

\section{ТОВЩА ЦЕОЛІТ-СМЕКТИТОВИХ ТУФІВ У НИЖНЬОВЕНДСЬКИХ ТРАПАХ ПІВДЕННО-ЗАХІДНОЇ ЧАСТИНИ СХІДНО-ЄВРОПЕЙСЬКОЇ ПЛАТФОРМИ, ЇХ ПОХОДЖЕННЯ ТА ПЕРСПЕКТИВИ ВИКОРИСТАННЯ \\ В.Г. Мельничук}

The results of researches of structure and composition of matter of layer are resulted zeolite- smectite volcanic tuffs in the lower-vendian trap-rocks of south-west part of East-European platform. Their origin and prospects of the use is considered. Key words: volcanic tuffs, trap-rocks, zeolites, smectites , minerals, vend.

Наведено результати досліджень будови і речовинного складу товщі цеоліт-смектитових вулканічних туфів в нижньовендських трапах південно-західної частини Східно-Європейської платформи. Розглянуто їх походження і перспективи використання.

Ключові слова: вулканічні туфи, трапи, цеоліти, смектити, корисні копалини, венд.

\section{ВСТУП}

Туфи, що розглядаються, - це продукти гідротермально-метасоматичних перетворень вулканічного попелу, піску та тефроїдннх вулканокластичних уламків від вулканічних вивержень базальтової магми у ранньому венді приблизно 600 млн років тому. Разом з базальтами і лавокластичними утвореннями туфи складають трапову формацію (волинську вулканічну серію) нижнього венду, поширену в південнозахідній частині Східно-Європейської платформи (СЄП) на стику Волино-Оршанського авлакогену і Балтійсько-Дністровського перикратонного прогину (рис. 1.) Туфи залягають шарами, формуючи на площі близько 200 тис. км² [1], гігантський вулканокластичний покрив потужністю до 210 м, відомий як бабинська світа, чи бабинські верстви пригоринської світи [15], перша товща ратайчицької світи [6]. Вони містять значну кількість цеолітів та смектитів ряду монтморилоніт-сапоніт, тому проявляють цінні сорбційні та катіонообмінні властивості. Існують перспективи їх використання як нетрадиційних для регіону корисних копалин [8] і потенційного об'єкта для підземного захоронення РАВ [9]. У Прип'ятському валу серед них виявлені стратиформні поклади самородної міді [10]. У зв'язку з цим подальші різнобічні регіонально-геологічні дослідження туфової товщі є актуальною задачею.

На сьогодні туфова товща загалом розкрита 440 свердловинами. 3 її порід отримано 163 визначення повного хімічного складу порід, виконано 555 аналізів на вміст міді і благородних металів, понад 1 тис. спектральних аналізів. В шліфах і аншліфах, штучних шліхах вивчено їх петрографічний i мінеральний склад.

Геологічні дослідження туфової товщі, виконані останніми роками в рамках ГДП - 200, ГГЗ-50 та при пошуках міді у Волино-Подільському регіоні, значно доповнили дані про її будову і речовинні особливості. Це дозволило внести певні корективи в уявлення про походження туфів і намітити нові шляхи їх господарського використання.

\section{БУДОВА ТУФОВОї ТОВЩІ}

Досліджувана туфова товща - частина великого поля розвитку трапів нижнього венду, що охоплює територію Поділля, Волині, південного заходу Білорусі та південного сходу Польщі. За даними глибинного геологічного картування вона простежуються під мезозойсько-кайнозойськими відкладами вздовж західного схилу Українського щита (УЩ) і Поліської сідловини у вигляді смуги шириною 1-10 км на глибинах від 5 до 250 м (рис. 1), звідки поступово занурюється на захід до глибин понад 4 км (свердловина Перемишляни). На денну поверхню туфи виступають лише в 5 км на південний схід від м. Славута Хмельницької області в кар'єрі Ташки, де видобуваються, та в базальтових кар'єрах Берестовець, Базальтове, Іванчі. На домезозойську поверхню туфова товща також виступає в межах 


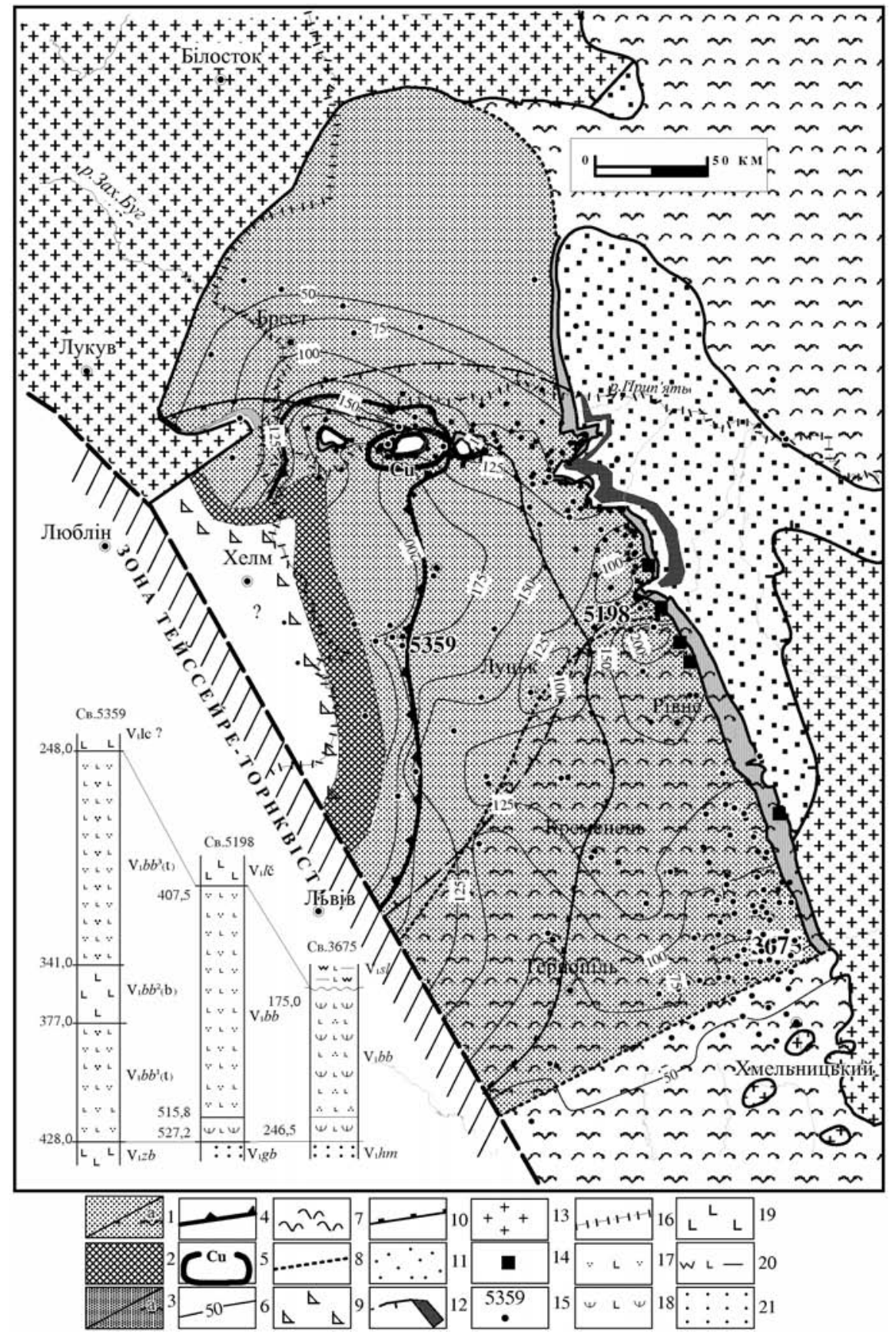

Pис. 1. Схема поширення та будови товщі цеоліт-смектитових вулканічних туфів нижнього венду в південно-західній частині СЕП

1-3 - ділянки поширення товщі цеоліт-смектитових туфів (а-3 шарами туфітів): 1 - під стратонами нижньовендської волинської серії, 2 - під стратонами верхньовендської могилів-подільської серії, 3 - під мезозойсько-кайнозойськими відкладами; 4 - контур покриву толеїтових базальтів в туфовій товщі; 5 - контур вивченого мідного зруденіння в горизонтах 2А і 25; 6 - ізопахіти туфової товщі; 7 - вулканогенно-осадові товщі нижнього венду; 8 - фаціальні границі; 9-10 - покриви олівінових базальтів заболотівської світи нижнього венду: 9 - під верхньовендськими відкладами, 10 - контур їх поширення під туфовою товщею нижнього венду; 11 - олігоміктові теригенні відклади поліської серії (середній-верхній рифей) та горбашівської світи (нижній венд); 12 - сили титанистих габро-долеритів пізнього венду ? та контур ї поширення; 13 - архейсько-нижньопротерозойський кристалічний фундамент; 14 - кар'єри, що розкрили туфову товщу; 15 - свердловини, що розкрили туфову товщу, та їх номер; 16 - державні кордони. На колонках: 17 - цеоліт-смектитові вулканічні туфи, 18 - туфіти, 19 - базальти, 20 - вулканоміктові алевроліти, 21 - олігоміктові пісковики і гравеліти, V1 - стратони нижнього венду (gb - горбашівська світа, bb - бабинська світа та бабинські верстви пригоринської світи, Іс- - лучичівські верстви), sl - слуцька світа, hm - хоморські верстви) 
Прип'ятського валу, навколо приядерних частин Хотешівської, Гірницької, Хотиславської і Славатицької горст-антикліналей, в Оваднівському піднятті і в Тельчинському куполі.

Непорушені розломами ділянки туфової товщі за площею становлять десятки і сотні квадратних кілометрів. В більшості з них нашарування туфів субгоризонтальне або слабо нахилене під кутами

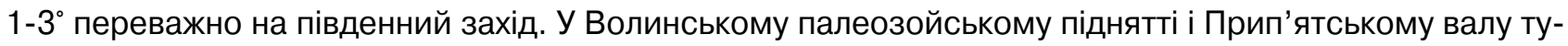
фова товща порушена численними розломами і деформована в пологі брахіскладки. Місцями нахил туфових верств тут досягає 15-30.

В південно-західній частині регіону, що примикає до краю СЄП, туфова товща в розрізі нижньовендської волинської серії (рис. 1) залягає на покривах олівінових базальтів (до восьми) заболотівської світи, а на західному схилі УЩ і Поліської сідловини - на олігоміктових теригенних відкладах горбашівської світи. В останньому випадку в основі розрізу товщі знаходиться пачка (до 20 м) туфітів. На більшій частинї регіону досліджувана товща перекрита численними покривами (до семи) базальтів ратнівської світи нижнього венду та її латеральних аналогів (третя товща ратайчицької світи та слуцька світа), а в місцях відсутності цих стратонів - верхньовендськими теригенними відкладами могилівподільської серії. Останні у верхів'ях р. Західний Буг залягають на туфовій товщі з глибоким розмивом (рис. 1).

Для туфової товщі властива порівняно слабка мінливість фацій і потужностей. Найбільшу потужність (до 210 м) вона, як і підстеляюча ефузивна заболотівська світа, має в південно-західній частині Волинського мегаблока, де Волино-Оршанський авлакоген сполучається з краєм СЕП (рис. 1). Тут розріз туфової товщі характеризується тричленною будовою. Верхня і нижня частини розрізу складені різнозернистими червоно- і строкатоколірними туфами з шарами і лінзами зеленоколірних різновидів. Їх розділяє покрив толеїтових базальтів потужністю від 7 до 47 м, під яким у Прип'ятському валу серед червоноколірної пірокластики поширені шари і прошарки зеленоколірних туфів з самородномідною мінералізацією (стратиформний міднорудний горизонт 2А [10,12]. Сам базальтовий покрив також міденосний (йому відповідає міднорудний горизонт 2Б). Міденосність зазначених горизонтів задовільно вивчена тільки в Прип'ятському валу, де вони виступають під домезозойську поверхню (рис. 1).

У східному напрямку, в районі 25-го меридіана, базальтовий покрив і зеленоколірні різновиди туфів, що залягають під ним, виклинюються, а потужність досліджуваної товщі поступово зменшується до 100 м. На латеральний їі розподіл найбільший вплив мають Горинська (Луцька) тектонічна зона, а також, ймовірно, зона Тейссейре-Торнквіста, простяганню якої відповідає загальний структурний план туфового покриву (зв'язок пірокластичних продуктів вулканізму і розломів детальніше розглянуто іншими авторами $[4,12])$.

На північному схилі Подільського виступу УЩ туфова бабинська світа фаціально заміщується туфогенними відкладами пригоринської світи, в якій, поряд з туфами, значну роль відіграють туфіти. Далі на південь вони переходять в осадові і туфогенно-осадові фації грушкінської світи нижнього венду. Разом з тим суттєво (до 40 м і менше) зменшується потужність цих відкладів. У Південно-Західній Білорусі, в районі Поліської сідловини, туфові верстви в складі ратайчицької світи також фаціально переходять в туфогенно-осадові відклади [6], а на захід від р. Західний Буг, в Біловежжі вони з нижньовендського розрізу виклинюються.

\section{ХАРАКТЕРИСТИКА ПОРІД}

В нижньовендському розрізі трапової формації регіону найбільше розповсюджені різнозернисті червоноколірні вулканічні туфи. Серед них незначне поширення мають шари і прошарки зеленоколірних туфів.

За розмірністю уламкового матеріалу виділяються псефітові, псамітові і пелітові різновиди. В залежності від форми і структурно-текстурних особливостей вулканокластичні уламки туфів поділяються на викинуті в твердому стані, викинуті в пластичному і напіврідкому станах і перевідкладені. Серед них зустрічаються уламки зі всією різноманітністю структур і складів, характерних для базальтових покривів заболотівської світи, що залягають під туфовою товщею. Окремі прошарки містять напівобкатані й обкатані, слабо сортовані уламки базальтів, шлаків, туфів, вулканічного скла діаметром до 10 мм і трактуються як вулканоміктові відклади. Іноді серед них трапляються окремі обкатані уламки кварцу і польових шпатів. 
За співвідношенням відсоткових вмістів уламків різних типів виділяються літо-вітрокластичні, літокластичні та вітрокластичні різновиди туфів. Цемент всіх різновидів туфів відноситься переважно до базального і змішаного, рідше - до контактно-порового, крустифікаційного і плівкового типів. За текстурними ознаками найбільше поширення мають туфи шаруваті, тонкошаруваті, косошаруваті, з перехрещеною шаруватістю. Іноді в них спостерігається градаційна верствуватість. В Прип'ятському валу серед туфів бабинської світи зустрічаються червоноколірні їх різновиди з добре вираженими пізолітовими кульками, виникнення яких пов'язується з випаданням в туфогенні відклади краплин дощу.

Червоноколірні туфи складені уламками магматичних порід: зміненого вулканічного скла, базальтів, шлаків, туфів, а також мінералів: плагіоклазів, піроксенів, рудних. Вулканічне скло значною мірою заміщено мікрокристалічними хлоритовими і смектитовими агрегатами, пігментованими червоним пилуватим гематитом та мартитом. Уламки скріплені цементуючими мінералами: в основному анальцимом, цеолітами, хлорит-смектитовими агрегатами, які в штучних шліхах домінують (табл. 1), рідше халцедоном, кальцитом, гідроксидами заліза. Зустрічаються також преніт, пумпеліїт, ломонтит. Серед цеолітів найпоширенішими $є$ натроліт, морденіт, томсоніт, птилоліт, гейландит. Рудні мінерали в одиничних знаках представлені уламковими магнетитом, піротином, хромітом, лейкоксеном, а також епігенетичними гематитом, піритом, халькопіритом та самородною міддю. Остання в туфах утворює розсіяні вкраплення, іноді дендрити і прожилки.

За даними комплексного рентгеноструктурного та термічного аналізів (14 визначень), в пелітових різновидах червоноколірних туфів Берестовецького кар'єру Рівненщина) в середньому міститься $64,8$ ( \pm 20$) \%$ смектитів діоктаєдричної будови ряду монтморилоніт-нонтроніт, гідрооксиди заліза, домішки кварцу і калієвого польового шпату. Псамітові різновиди червоноколірних туфів, отримані із свердловин поблизу Рафалівського кар'єру, в середньому (6 визначень) містять 65.0 ( \pm 15.0$) \%$ смектитів триоктаедричної будови ряду гекторит-сапоніт та 28,2 (ะ14,6)\% анальциму та цеолітів.

Таблиця 1. Мінеральний склад (\%) вулканічних туфів бабинської світи за даними повного мінералогічного аналізу (околиці с. Іванчі Володимерецького району)

\begin{tabular}{|l|c|c|c|c|c|c|c|}
\hline № свердловин & 19 & 17 & 8 & 20 & 13 & 14 & Середнє \\
\hline Глибинавідбору, м & 54,5 & 58,4 & 60,0 & 61,0 & 62,0 & 62,0 & \\
\hline Цеоліти & 39,15 & 46,23 & 33,50 & 45,40 & 47,51 & 47,35 & 43,19 \\
\hline Смектити & 59,62 & 42,83 & 31,54 & 54,78 & 50,83 & 51,08 & 48,53 \\
\hline Польові шпати & 0,92 & 9,13 & 13,73 & 1,6 & 0,89 & $3 \mathrm{H}$. & 5.25 \\
\hline Магнетит & 0,30 & 1,49 & $3 \mathrm{H}$. & 0,22 & 0,77 & 1,57 & 0,87 \\
\hline Мартит & 0 & 0 & 3,52 & 0 & 0 & 0 & 0,59 \\
\hline Кварц & 3н. & 3н. & $3 \mathrm{H}$. & 0 & 0 & $3 \mathrm{H}$. & $3 \mathrm{H}$. \\
\hline Хлорит & 3н. & 3н. & $3 \mathrm{H}$. & 0 & $3 \mathrm{H}$ & $3 \mathrm{H}$. & $3 \mathrm{H}$. \\
\hline Піроксен & 0 & 0,22 & 0 & 0 & $3 \mathrm{H}$. & $3 \mathrm{H}$, & 0,06 \\
\hline Муть & 0 & 0 & 17,66 & 0 & 0 & 0 & 2,94 \\
\hline Сума & 99,99 & 99,90 & 99,95 & 102,00 & 100,00 & 100,00 & 100,31 \\
\hline
\end{tabular}

* Аналізи виконані в мінералогічній лабораторії Рівненської геологічної експедиції ПДРГП Північгеологія.

Червоноколірні різновиди туфів, що містять високі концентрації цеолітів і смектитів, проявляють цінні сорбційні та катіонообмінні властивості. Так, за матеріалами В.О. Грицика, П.О. Ляшенко (1997) в анальцим-сапонітових туфах Варварівського родовища (Славутський район Хмельницької області) вибіркова адсорбція радіоцезію $\mathrm{Cs}^{137}$ при початковій радіоактивності середовища 46000 Бк (Т:P = 1:10) становить 99,5\%, а адсорбція радіостронцію $\mathrm{Sr}^{90}$ при початковій радіоактивності середовища 3900 Бк (Т:Р = 1:10) досягає 97,0\%. Ємкість катіонного обміну в цих туфах сягає 74,7 мг.екв./100 г. До

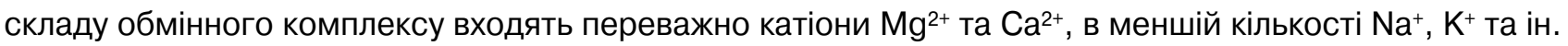
Загалом цеоліт-смектитові різновиди охарактеризованих туфів за хімічним складом і властивостями близькі до бентонітів. За хімічним складом (табл. 2) червоноколірні туфи загалом відповідають натрієвим базальтам сублужного ряду і суттєво відрізняються від толеїтових базальтів, що залягають серед них в західній частині регіону у вигляді покриву, порівняно низькими вмістами $\mathrm{CaO}, \mathrm{FeO}$ та підвищеною кількістю $\mathrm{Fe}_{2} \mathrm{O}_{3}, \mathrm{Na}_{2} \mathrm{O}, \mathrm{K}_{2} \mathrm{O}$, в.п.п. а також вмістами розсіяних елементів. 
Таблиця 2. Середній хімічний склад порід туфової товщі нижнього венду

\begin{tabular}{|c|c|c|c|c|c|c|c|c|c|c|c|c|}
\hline \multirow[t]{2}{*}{ Порода } & \multicolumn{11}{|c|}{ Петрогенні компоненти, ваг.\% } & \multirow{2}{*}{$\begin{array}{c}\text { Кількість } \\
\text { проб }\end{array}$} \\
\hline & $\mathrm{SiO}_{2}$ & $\mathrm{TiO}_{2}$ & $\mathrm{Al}_{2} \mathrm{O}_{3}$ & $\mathrm{Fe}_{2} \mathrm{O}_{3}$ & $\mathrm{FeO}$ & $\mathrm{MnO}$ & $\mathrm{MgO}$ & $\mathrm{CaO}$ & $\mathrm{Na}_{2} \mathrm{O}$ & $\mathrm{K}_{2} \mathrm{O}$ & $\mathrm{P}_{2} \mathrm{O}_{5}$ & \\
\hline Туфи червоноколі рні & 47,49 & 1,87 & 13,57 & 10,7 & 2,81 & 0,19 & 7,18 & 3,06 & 4,7 & 1,37 & 0,15 & 147 \\
\hline Туфи зелено колірні & 47,08 & 1,42 & 13,92 & 7,37 & 4,28 & 0,22 & 7,06 & 7,58 & 3,78 & 0,92 & 0,11 & 16 \\
\hline Базальти & 46,48 & 1,48 & 15,86 & 7,82 & 5,68 & 0,26 & 6.57 & 7,84 & 3,19 & 1,05 & 0,22 & 56 \\
\hline \multirow{2}{*}{ Порода } & \multicolumn{11}{|c|}{ Розсіяні елементи (в n x 10-4 г/т) } & \multirow{2}{*}{$\begin{array}{c}\text { Кількість } \\
\text { проб }\end{array}$} \\
\hline & $\mathrm{Ba}$ & $\mathrm{Pb}$ & $\mathrm{Cr}$ & $\mathrm{Ni}$ & $\mathrm{Co}$ & $\mathrm{V}$ & $\mathrm{Cu}$ & $\mathrm{Zn}$ & $\mathrm{Zr}$ & $\mathrm{Sr}$ & $\mathrm{Sc}$ & \\
\hline Базальти & 195 & 4 & 86 & 74 & 15 & 156 & 90 & 89 & 119 & 116 & 24 & 221 \\
\hline Туфи червоноколі рні & 208 & 4 & 81 & 50 & 26 & 187 & 64 & 77 & 152 & 109 & 18 & 1437 \\
\hline Туфи зеленоколірні & 299 & 6 & 69 & 50 & 41 & 257 & 67 & 88 & 179 & 103 & 28 & 60 \\
\hline Кларкові вмісти & 290 & 6 & 230 & 80 & 30 & 300 & 90 & 84 & 150 & 460 & 30 & \\
\hline
\end{tabular}

Зеленоколірні туфи складаються переважно з рівнокрупних уламків пористого вулканічного скла, рідше базальтів, а також піроксенів, плагіоклазів і магнетиту. Вулканічне скло в частині уламків практично не змінене, в інших - заміщене монтморилоніт-хлоритовими агрегатами, які виповнюють $\mathrm{i}$ пустоти. В цементі зеленоколірних туфів також переважають смектит-хлоритові агрегати за участю халцедону, анальциму і цеолітів. В хлоритизованих туфах присутня тонкорозсіяна вкрапленість магнетиту і самородної міді. Остання місцями має в туфах промислові концентрації утворює стратиформний міднорудний горизонт 2А потужністю до 2,2 м.

За хімічним складом (табл. 2) зеленоколірні туфи значно ближчі до толеїтових базальтів, ніж червоноколірні, це пояснюється їх порівняно слабкішими гідротермально-метасоматичними перетвореннями.

\section{ПОХОДЖЕННЯ ЦЕОЛІТ-СМЕКТИТОВИХ ТУФІВ}

Стійке поширення потужної пірокластічної товщі по всій території розвитку нижньовендських трапів у південно-західній частині СЄП свідчить про те, що в процесі волинського вулканізму існував самостійний у часі етап, який характеризувався потужною експлозивною діяльністю. Нагромадження пірокластичної товщі на південно-західному краю СЄП, згідно з поглядами автора, відбувалося в континентальних умовах, на широкому траповому плато, складеному численними наземними покривами олівінових базальтів заболотівської світи, що примикали до Галицької геосінкліналі (палеокеану Япетус).

На континентальні умови накопичення пірокластичної товщі вказують такі ознаки: значне переважання в складі туфів закисного заліза, гематитизація вулканічного скла і порід у вулканокластичних уламках, слабка сортованість і низький ступінь механічної обробки уламкового матеріалу, поширення в туфах пізолітів. Вулканоміктові прошарки серед туфів мають ознаки делювіальних і пролювіальних відкладів, що свідчить про можливість широкого розносу пірокластичних уламків і тефри тимчасовими водними потоками. Покрив толеїтових базальтів у розрізі туфової товщі має зональну будову, характерну для наземних ефузивів, і не містить подушкової окремішності.

Місцезнаходження джерел пірокластичного матеріалу в регіоні точно не встановлено. Судячи з ділянок максимальної потужності пірокластичної товщі і наявності в її розрізі базальтового покриву, джерела виверження пірокластики могли знаходитись у верхів'яхічок Прип'ять і Західний Буг, на ділянці, що прилягає до краю СЄП. Послідовне збільшення у північно-західному й західному напрямках вмісту пірокластики в туфовій товщі, а також зростання в цьому напрямку кількості і потужності ефузивних покривів у розрізі волинської серії підтверджують таке припущення.

Зв'язок пірокластичного матеріалу, пов'язане з вулканічними апаратами центрального типу (стратовулканами), які виділялись Б.Я. Воловник у межах осьової зони Волино-Поліського прогину [4], на сьогодні видається мало ймовірним. Спроби реконструювати зазначені вулканічні споруди серед пірокластичної товщі виявились безуспішними через незначну її потужність (100-200 м) та слабку фаціальну мінливість.

Наприкінці раннього венду породи волинської трапової формації в центральній частині успадкованого Волино-Поліського прогину зазнали глибоких метасоматичних перетворень і зональної гідротермальної мінералізації [7]. Підігрів басейнових формаційних вод (зокрема горбашівського водо- 
носного горизонту) був спричинений, ймовірно, силами титанистих габро-долеритів, що локалізувались під трапами серед відкладів рифейської поліської серії (рис. 1). Мінеральні новоутворення, які виникли в туфовій товщі під їх дією, складають цемент кластогенних порід, виповнюють численні пори та тріщини, заміщують первинні мінерали і вітрофірові продукти. За типоморфними мінеральними асоціаціями, глибиною і масштабами перекристалізації порід, а також температурними параметрами мінералоутворення [3], ці зміни відповідають цеолітовій і преніт-пумпеліїтовій фаціям метаморфізму [7]. Ізотопний склад кисню мінералізуючих розчинів відповідає в одних випадках такому для магматичної [3], в інших - для формаційної [16] води. Внаслідок зазначених змін, в туфах найбільшого поширення набула хлорит-смектитова і цеолітова мінералізації, яку зумовили розглянуті нижче корисні властивості туфової сировини.

\section{ПЕРСПЕКТИВИ ВИКОРИСТАННЯ ТУФОВОЇ СИРОВИНИ}

Досліджувані цеоліт-смектитові вулканічні туфи віднедавна розглядаються $[2,5,8,11]$ як нетрадиційний для регіону вид мінеральної сировини, придатної для широкого господарського використання (рис. 2).

Технологічні випробування показали, що борошно з пелітових туфів Берестовецького кар'єру (Рівненщина) з добавкою 1,0\% мазуту спучується при температурі $1020^{\circ} \mathrm{C}$ і $є$ придатним для виготовлення керамзиту. 3 них можна виготовляти також пігменти для фарб та кольорових бетонів. 3 борошна туфів Рафалівського кар'єру отримано дослідні зразки якісних керамічних виробів [5]. На Іванчівському родовищі (Рівненщина) туфи розвідані як сировина для виготовлення портландцементу.

\begin{tabular}{|c|c|c|c|c|c|c|c|c|}
\hline \multicolumn{9}{|c|}{$\begin{array}{lllllll}\text { О } & \text { Б } & \text { Л } & \text { А } & С & \text { Т } & \text { । }\end{array}$} \\
\hline \multicolumn{3}{|c|}{ Природоохоронні заходи } & \multicolumn{3}{|c|}{ Сільське господарство } & \multicolumn{3}{|c|}{ Будівельна індустрія } \\
\hline 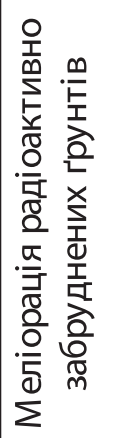 & 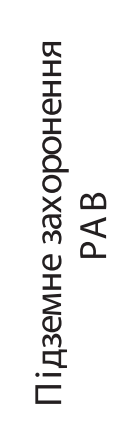 & 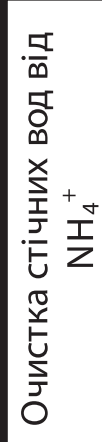 & 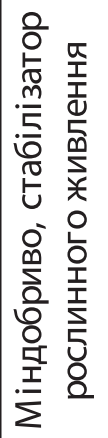 & 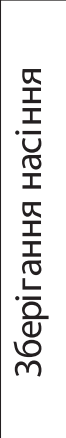 & 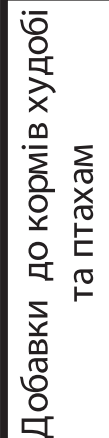 & 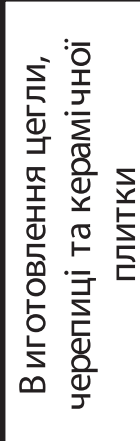 & 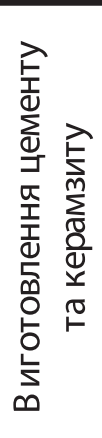 & 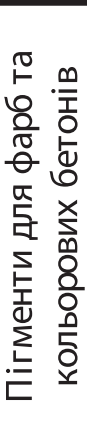 \\
\hline
\end{tabular}

Рис. 2. Можливості господарського використання цеоліт-смектитових туфів регіону

Проведені польові дослідження на землях запасу Шубківської сільської ради (Рівненщина) показали позитивну дію туфів Берестовецького кар'єру на врожай картоплі і кукурудзи на силос з приростом врожайності. Дослідні внесення туфів у радіоактивно забруднені дерново-підзолисті ґрунти Рівненщини засвідчили ефективність застосування цих меліорантів для зниження вмісту ізотопів Sг137 в сільськогосподарських культурах. Позитивна комплексна дія туфового борошна проявляється також в таких явищах у ґрунтах: а) нормалізації азотного та калійного живлення, б) зменшенні кислотності, в) збалансуванні вмістів мікроелементів, г) утриманні вологи та регулюванні водозабезпеченості рослин, д) збільшенні поглинаючої здатності ґрунтів. Досліджується також придатність туфів для ізоляції побутових відходів, очистки стічних і ставкових вод.

Інститутом кормів УААН (м. Вінниця) та Державним контрольним науково-дослідним інститутом ветпрепаратів і кормових добавок (м. Львів) розроблені технічні умови (ТУУ 46.15.ГО 026-2001), за якими подрібнені туфи та розроблені на ї основі препарати (Зернол-2, Галосил), рекомендується використовувати як ефективний мінеральний консервант, що зберігає вологе зерно, силос і сінаж без втрат з одночасним підвищенням продуктивної дії фуражу. Туфовий препарат Анальцим, який виробляє і постачає ТОВ Аутлук (м. Рівне), рекомендовано вводити до складу комбікормів для великої рогатої худоби, свиней, птиці та звірів. 
Прогнозні ресурси туфової сировини в регіоні становлять сотні міліонів тон, тобто є практично невичерпними. Запаси туфової сировини, тільки в контурах базальтових кар'єрів Рівненщини площею 86 га при заглиблені на 10 м, за приблизною оцінкою становлять 20 млн. т. Для практичного використання туфової сировини немає потреби в попередньому збагаченні. Приповерхні умови залягання туфів дозволяють видобувати ї відкритим способом, насампередз дна відпрацьованих базальтових кар'єрів, без затрат на розкривні роботи, спорудження під'їзних шляхів та гірничодобувної інфраструктури.

Із зеленоколірними смектит-хлоритовими різновидами туфів у Прип'ятському валу пов'язане стратиформне самородномідне зруденіння в горизонті $2 \mathrm{~A}[7,10,12]$. Останній разом з іншими міднорудними горизонтами в трапах, за попередніми техніко-економічними міркуваннями є придатним для промислової розробки, а туфові мідні руди і гірнича маса мають перспективу комплексного використання на мідь і туфове борошно.

Потужна товща розглянутих цеоліт-смектитових туфів завдяки своїм унікальним ізоляційним і сорбційним властивостям, сприятливим інженерно-геологічним умовам залягання та близькості до Рівненської і Хмельницької атомних електростанцій репрезентована нами також як потенційний альтернативний об'єкт для підземного захоронення радіоактивних відходів [9].

\section{ВИСНОВКИ}

Вулканічні туфи нижнього венду в південно-західній частині СЄП утворюють широкий пірокластичний покрив, витягнутий вздовж її краю. Біля краю платформи зростає потужність туфової товщі, а в її розрізі значного поширення набуває покрив толеїтових базальтів. Це свідчить про ймовірну ендогенну активність краєвої шовної зони Тейссейре-Торнквіста в ранньому венді.

Розглянуту туфову товщу і породи, що їі складають, з огляду на особливості їх хімічного складу і будови, слід відносити до континентальних утворень трапової формації, що зазнали епігенетичних гідротермально-метасоматичних змін під дією басейнових формаційних і магматичних вод.

За хімічним і мінеральним складом сильно змінені червоноколірні туфи суттєво відрізняються від базальтів. Їх основною особливістю $€$ епігенетична цеолітова і хлорит-смектитова мінералізація, що обумовлює корисні властивості туфової сировини.

Позитивні властивості цеоліт - смектитових туфів та доступне залягання дозволяють розглядати їх як новий для регіону вид мінеральної сировини, придатної до широкого господарського використання в природоохоронних заходах, сільському господарстві та будівельній індустрії.

Покрив толеїтових базальтів серед туфової товщі в Прип'ятському валі контролює міднорудні горизонти 2А і 2Б. Він поширеннений також в південно-західній, побузькій, ще добре не дослідженій частині регіону, у зв'язку з чим існує ймовірність виявлення тут нових стратиформних покладів міді.

1. Бирюлев А.Е. Распостраненность продуктов вендского вулканизма в юго-западной части Русской платформи // Докл. АН СССР. - 1969. - том.189, № 2. С. 366-368.

2. Богданов Г.О., Мандигра М.О., Мельничук В.Г. та ін. Цеоліт-смектитові туфи Рівненщини: біологічні аспекти використання. - Рівне: Волинські обереги, 2005. $184 \mathrm{c}$.

3. Деревская К., Шумлянский В., Галецкий Л. И др. Геолого-генетическая модель рудообразующей системи и поисковы признаки самородномедного оруденения в трапах Волыни // Геолог України. - 2003. - № 3, 4. C. $75-81$.

4. Волокник Б.Я. Пирокластические породи Волыни. // Пирокластические породы Украины. - Киев: - Наук. думка, 1977. - С. 70-83.

5. Дворкін Л.Й., Скрипник І.Г., Нехаєва Л.І., Яковеко В.Ю., Стасюк І.Б. Дослідження фізико-механічних властивостей базальтового туфу як сировини для будівельної кераміки // Ресурсоємкі матеріали, конструкції, будівлі та споруди. - Рівне. - 1996. C. 24-25.

6. Махнач А.С, Гарецкий Р.Г., Матвеев А.В. и др. Геология Бєларуси - Минск, 2001. - 815 с.

7. Мельничук В.Г. Гідротермальна мінералогічна зональність та метаморфізм в міденосних трапах нижнього венду Волино-Подільської плити // Мінер.зб. лНу. - 2004. - вип. 2. - С. 131-142.

8. Мельничук В.Г., Матеюк В.В. Туфи Волино-Поділля як новий вид мінеральних ресурсів // Проблеми раціонального використання, охорони і відтворення природно-ресурсного потенціалу України. - Чернівці: - Рута, 2000. - С. 133-134.

9. Мельничук В.Г., Поліщук А.М., Мельничук Г.В. Вулканічні туфи в трапах Волино-Поділля як альтернативний об'єкт для захоронення радіоактивних відходів: 
Зб. наук. пр. // Вісн. НУВГП. - Вип. 5 (18), ,ч. 1. Рівне. - 2007. - С. 107-113.

10. Мельничук В.Г. Стратиграфічні чинники мідноносності нижньовендських трапів Волині (Прип'ятський вал) // Зб. наук. пр. УкрДГРІ. - 2008. - № 1. - С. 50-58.

11. Мельничук В.Г. Цеоліт-смектитові вулканічні туфи Волині - новий тип природної агрохімічної сировини // Агрономічні руди України. - К., - 2004. - С. 117-119.

12. Приходько В.Л. Перебудова структурного плану та етапи трапового вулканізму Волино-Поділля в пізньому протерозої: - Автореф. дис. канд. геол. наук. - К., 2005. - 31 c.

13. Скакун Л., Ткачук А., Мельничук В. Типи цеолітових асоціацій в гідротермальних утвореннях волинської серії // Мінерал.зб. ЛНУ. - 2003. - № 53, - вип. 1-2. - С. 4-13.
14. Скрипник І.Г., Ніхаєва Л.І., Філоненко В.В. Дослідження фізико-хімічних властивостей базальтового туфу як сировини для будівельної кераміки // Матеріали наук.техн. конф. УПВГ. - Рівне, - 1995. - С. 24-27.

15. Стратиграфические схемы фанерозойских образований Украины для геологических карт нового поколения (графические приложения). - Киев: Гео прогноз, . 1993.

16. Шумлянский В.А., Деревская Е.И., Сингаевский Е.Д., Черникова Н.С. Медно-цеолитовая минерализация в базальтових туфах на западном склоне Украинского щита и природа минерализующих растворов // Докл. АН УССР. Геохимия. - 1991. - № 9. С. $140-143$.

Rivne geological expedition of PDRGP «Pivnichgeologiya», Rivne, Ukraine

Рівненська геологічна експедиція ПДРГП «Північгеологія», м. Рівно, Україна 